DOI: https://doi.org/10.31392/NPU-nc.series9.2018.18.08

UDC: 81.13

Yuliia V. Kravtsova

National Pedagogical Dragomanov University,

Kyiv, Ukraine

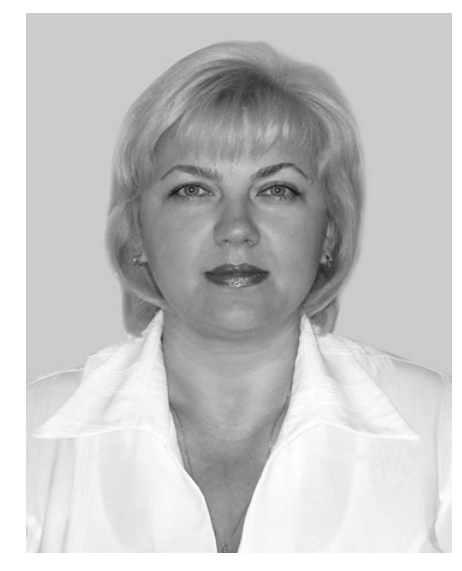

\title{
METAPHORIC MODELLING IN MODERN LINGUISTICS
}

\section{Bibliographic Description:}

Kravtsova, Yu. V. (2018). Metaphoric Modelling in Modern Linguistics. Scientific Journal of National Pedagogical Dragomanov University. Series 9. Current Trends in Language Development, 18. 95-106. DOI: https://doi.org/10.31392/NPU-nc.series9.2018.18.08

\begin{abstract}
In modern science modelling is one of the main methods of scientific research. Metaphor began to be considered as a simulated object only from the end of the last century. In Eastern Slavic linguistics two approaches to modelling of metaphorisation have emerged - semantic and cognitive. Based on the analysis of linguistic studies in the sphere of metaphorical modelling, various ways of parametrising metaphors as a semantic and cognitive model have been characterized, their common parameters have been established, disputable questions have been highlighted. The author has developed a new semantic-cognitive approach to the study of metaphor and modelling of metaphorisation. According to it, metaphor is considered as a mental and verbal construct created in the process of human metaphorogenic activity. However, the study of cognitive mechanisms, including metaphorisation, is possible only based on the research of the results of their realisation in language (speech). Through the study of the semantics of the metaphorical nominations of a language and the construction of corresponding metaphorical models, the semantic-cognitive approach allows to establish the models of national metaphorical thinking characteristic of any historical period. The main points of this approach are briefly outlined, a parametric description of the metaphor as a semantic-cognitive model is represented, a rationale for the introduced notions of metaphorical mega-model and sub-model, semantic-cognitive formant is provided. The proposed technique is intended both for corpus research of metaphors and for the study of separate facts of a metaphorical nomination.
\end{abstract}

Keywords: metaphor, metaphorisation, metaphorical modelling, metaphorical model, parameter of model, sphere-source, sphere-target.

\section{Introduction.}

In modern science, modelling is one of the main tools for understanding the world, which is determined by the logic of the development of various scientific fields and the expediency of indirectly studying of individual fragments of objective reality. The methodology of modelling has a great research potential, the implementation of which contributes to the penetration into the essence of many complex phenomena of reality. 
Modelling as a way of understanding the world that arose in ancient times received a wide recognition in many fields in the XX century (Glushkov, Ivanov, Vedenov, Shtoff et al.). It happened thanks to the intensive development of mathematical methodology; that is why new research opportunities and prospects of this method appeared in the disclosure of general laws and structural features of systems of different nature. In the XXI century modelling is actively used in a variety of scientific fields, due to the rapid growth of computer technology and the expansion of technical capabilities for obtaining new knowledge.

The study of language as an object inaccessible for direct observation implies an analysis of the results of mental-verbal processes in the human mind that is expressed in written (text, discourse) and oral speech. Therefore, modelling is one of the most important methods of linguistic research. In linguistic methodology, modelling is considered as a method of studying the properties and structure of linguistic units or phenomena based on the study of the properties and structure of their model.

The notions of model and modelling were first used in linguistics by the adherents of structuralism in the first half of the XX century (Bloomfield, Harris et al.). They did not set the global task of creating a general linguistic theory that would explain the phenomena of a language and their interrelations, but they developed the methods for modelling and synchronous description of a language. The terms "model" and "modelling" were introduced in 1950-1960 in a broad linguistic context in connection with the emergence of mathematical linguistics, which developed a formal apparatus for describing the structure of natural and artificial languages, as well as the penetration of mathematical methods into linguistics (Apresyan, Revzin et al.). At the same time, the views were expressed both about the limited possibilities of this method, despite its universality (Apresyan, 1966), and about the danger of narrowing the science of language caused by the emerging theory of models (Losev, 1968). The latter was considered not only to be the mathematical or logical theory, but the linguistic one (Revzin, 1978). Currently, modelling is actively used in linguistics and in unity with other methods of language learning is acted as a means of deepening the knowledge of hidden mental-linguistic mechanisms.

In recent years, modelling has become one of the leading methods for studying metaphors, since the active study of metaphorisation led scientists to understand metaphors as a simulated object (Balashova, Baranov, Teliya, Chudinov et al.). The imaginative mentalverbal activity of native speaker is carried out according to certain, relatively limited models. Metaphorical nominations resulting from cognitive processes, which are directly influenced by language and the method of conceptualization of reality characteristic of a given culture, are accumulated by an ethnos during its historical development. As a result, a metaphorical picture of the world is formed and modified, revealing a certain stereotype of national figurative thinking. In different periods of the existence of a language, certain metaphorical models are inherent in it (Balashova, Baranov, Kravtsova, Chudinov et al.).

The analysis of publications on the problem of metaphorical modelling (Baranov, Kudryavtseva, Laguta, Rezanova, Teliya, Tropina, Chudinov et al.) showed that modelling as a method of linguometaphorological research is still in the formative stage: there are relevant metalinguistic differences in the use of terminology in characterising metaphorical modelling, so there is no clear boundaries of the description of the simulated object; definitions of the metaphorical model and modelling in connection with the wide application of these concepts are somewhat amorphous; due to the ambiguity of the interpretation of the metaphorical model and modelling their characteristics are difficult to determine; the use of models and modelling in other branches of linguistics creates issues with the definition of the status and boundaries of the description of the object being modelled. Consequently, the use 
of modelling in linguometaphorology requires further unification of its categorical and conceptual apparatus.

\section{Modelling in Linguometaphological Studies.}

In the Eastern Slavic linguometaphorology, two main approaches to metaphorisation modelling have emerged - semantic and cognitive. The semantic approach continues the traditions of linguistic semantics and proceeds along the lines of semantic derivatology in the context of key points of cognitology (Kudryavtseva, Laguta, Sklyarevskaya, Tropina et al.). The cognitive approach is based on the postulates of linguistic cognitive science taking into account the achievements of linguistic semantics (Baranov, Budaev, Chudinov et al.). According to these approaches, metaphor is regarded respectively as a semantic and cognitive model. Quite a few applied studies have been devoted to establishing and describing specific metaphorical models in different genre-style differentiation texts and discourses (Filatenko, Solodovnikova et al.), but many questions still remain unresolved or debatable.

Within the framework of semantic and cognitive metaphorical modelling, there are different ways of parametrising metaphorical models, the principles of their description and classification. However, despite the differences, there are similar features: the unity of the basic concepts of metaphorical modelling (with different terminology), operating with the same term "metaphorical model", a commonality in the selection of such model parameters as the source sphere and the target sphere of metaphorical projection.

\subsection{Metaphor as Semantic Model.}

From the standpoint of linguistic semantics, metaphorical modelling can be described as the construction of metaphorisation models that demonstrate the regular transfer of names from one class of objects to another based on the similarity of their characteristics and reflecting the specificity of the ethnos figuratively-associative thinking at a certain stage of its development. Modelling is a "powerful learning tool and a convenient way to describe motivational-derivational processes. The introduction of the notion of the model makes it possible to move from the scattered facts of the vocabulary replenishment using the method of semantic derivation [...] to generalizations. It makes it possible to see the particular manifestations of the patterns characteristic of the semantic development of words" (Tropina, 2003: 116).

The term "model" ("semantic model") in linguistic semantics first appeared in the work of Shmelev in describing regular polysemy. He noted the prevalence of "context-specific metonymic substitutions based on a certain more or less stable semantic model" (Shmelev, 1964: 54). The scholar emphasized the need for words to be included in one semantic unification as an indispensable condition for the development of parallelism of semantic structures. However, at that time the term "model" as applied to the results of the secondary nomination was not widely used and began to be used only in the late 1980s: "Essentially, a metaphor is the model that performs the same function in the language as the derivational model, but only more complex and, moreover, acting "hidden" and non-standard" (Telia, 1988: 38).

The understanding of a metaphor as a semantic model is based on the theory of regular ambiguity (Shmelev, Apresyan et al.). In accordance with the semantic approach, every model predetermines the possibility of transforming the meanings of words that are close in meaning. However, the metaphor as a semantic model is interpreted ambiguously: a way of formation that takes into account the denotative-conceptual meaning of the motivating and motivated sememes, as well as the semantic formant (Tropina); regular transfer of words, ideographically correlative, from one class of objects to another based on the similarity of 
their properties; typical correlation of direct and figurative meanings for thematically close words (Ponomareva, Sklyarevskaya et al.), etc. Thus, the metaphorical model is interpreted as a regular relationship between denotative-conceptual spheres deriving and derived meanings of words based on a certain semantic motivation.

It should be noted that in semantic studies the descriptions of metaphorical models have significant differences in the characteristics of their parameters both in quantitative and qualitative terms: the basis of metaphor as the thought of the world (object, event, property, etc.); some figurative representation of auxiliary entity; the very meaning of the reinterpreted name (Teliya); archiseme, the replacement of which is carried out; the seme updated in derivative; new differential semes (Kudryavtseva); agent (parameter word); main and auxiliary subjects (figurative and direct meanings); attributable properties of objects; base of comparison; context (argument word) (Balashova); parameter word (image carrier); argument word (microcontext) (Vardzelashvili); ideographic relatedness of motivating and derived meanings (sphere of donor and sphere of recipient); lexicosemantic group of motivating and derived meanings; lexical meaning of motivating and motivated meanings; meaningful and formal characteristics of semantic formants (Tropina), etc. For example, the metaphorical model can be described in the folloaing way: functional transfer from the anthroposphere to the sphere of artifacts; motivating lexicosemantic group "person" replenishable lexicosemantic group "mechanism"; nomination: person by occupation is a mechanism that performs a similar function; semantic formant: differential seme with the meaning of a specific function, maintaining its status in a motivated meaning (заправщик, калькулятор, etc.) (Tropina, 2003: 124).

In the works describing the results of semantic modelling of metaphorisation is carried out the classification of metaphorical models for various criterions based on the analysis of a significant amount of language data (Kudryavtseva, Laguta, Sklyarevskaya, Vardzelashvili et al.). Thus, Sklyarevskaya (1993), relying on the data of ideographic dictionaries, describes the regular models of substantive metaphorisation established by it on the data of the explanatory dictionaries of the Modern Russian language. It indicates the sphere-source of metaphorisation and the direction of the metaphorical projection: e.g., "Animal $\rightarrow$ Human" (осел, петух); "Human $\rightarrow$ Human" (актер, барин); "Item $\rightarrow$ Human" (лопух, пробка); "Subject $\rightarrow$ Subject" (гора книг, джунгли города), etc.

Thus, in accordance with the semantic approach, every model predetermines the possibility of converting the meanings of words close in meaning to each other. Modelling can be based on various principles, which is accordingly reflected in the nature of parameterisation and classification of models. Therefore, when describing metaphors as a semantic model, denotative-conceptual spheres are most often characterized (or other semantic associations - lexicosemantic / thematic groups, semantic fields, etc.), which include the corresponding words in primary and secondary (metaphorical) meanings, as well as motivating metaphorical transference signs. In various semantic studies, the metaphorical models include components of different nature and quantity, but the separation of ideographic spheres of deriving and derived meanings is similar. Such works are usually characterised by a thorough consideration of the facts of a secondary nomination. Based on component analysis, it contributes to a deep insight into the essence of metaphorisation. However, such descriptions of metaphorical models are carried out, as a rule, on a relatively small amount of data, often of a selective nature. It is characterized by the complexity of structuring and the ambiguity of parameterisation of models. 


\subsection{Metaphor as Cognitive Model.}

Metaphorical modelling in the linguocognitive aspect is a means of comprehending, categorizing, presenting and evaluating reality, reflecting national self-consciousness at a certain stage of development of society (Budaev, Chudinov et al.).

Understanding of a metaphor as a cognitive model established in East Slavic cognitive linguistics (in Western European and American cognitive linguistics, the term "model" is practically not used in relation to metaphor) is based on a mental phenomenon reflecting the process of cognition of the world and fixed in language. Metaphor as a cognitive model is interpreted in different ways: thematic field of significate descriptors; the sphere of the source, whose elements are connected by various semantic relations (Baranov, Kobozeva et al.); an existing or emerging in the minds of native speakers a communication scheme between two conceptual spheres, which can be represented by a certain formula: " $\mathrm{X}$ is $\mathrm{Y}$ " (Budaev, Chudinov et al.); projecting the source sphere onto the target sphere, as a result of which this or that denotative sphere receives insight and figurative representation using concepts that are borrowed from another sphere closer and more comprehensible to native speakers (Ryaposova); projecting the source sphere onto the target sphere (Kabachenko et al.), etc. Thus, the metaphorical model is considered in two ways: most often as a correlation between the source sphere and the target sphere of the metaphorical projection (the interaction of two conceptual spheres), fixed in the language and reflecting the nationalcultural traditions of a given society, more rarely as a conceptual sphere, correlated with the sphere of the source of metaphorisation.

In cognitive linguometaphorological studies, the parameters of a metaphorical model are described in different ways: a significate descriptor; tree of the significate descriptor (Baranov); initial conceptual domain (source sphere, donor sphere); new conceptual domain (target sphere, recipient sphere); typical scenarios; frames; typical frame slots; the component that connects the primary and secondary meanings of words (Chudinov); source sphere; sphere of metaphorical attraction (sphere-target, sphere-aim); source sphere and / or target sphere frames; slots of sphere-source and / or sphere-target frames (Shinkarenkova); initial conceptual sphere; new conceptual sphere; conceptual subsphere; model indicators: frequency, productivity, dominance (Kerimov), etc.

Within the framework of cognitive modelling of metaphorisation, there are two leading theories - descriptor (Baranov) and cognitive-discursive (Chudinov) theories. They suggest the appropriate metaphorical model building techniques for corpus research of metaphors in some discourse; although metaphorical model is interpreted in them in different ways, which is reflected in the principles of modelling, parametrization, classification and description of models.

In accordance with descriptor theory (Baranov, 2004, 2006, 2014), the metaphorical model (M-model) is a thematic field of significate descriptors. Every descriptor includes the hierarchically ordered "trees". The author of this theory identifies M-models of war, sports, games, transport, machinery, family relations, fauna, etc., structured in the form of "trees". For example, the metaphorical model "War" includes several conceptual spheres "weapon", "types of military actions", "participants of military actions", etc., which, in turn, are formed by a set of terminal concepts: "weapon"- винтовка, меч, динамит, etc.

The method of analysis and corpus description of metaphor proposed by Baranov makes it possible to use standard computer data processing tools and to involve for analysis considerable amounts of actual (language) information, which significantly increases the reliability of the obtained results. The corpus inventory of metaphorical models is an important stage in the scientific description of the functioning of metaphors in real use, as 
evidenced by the emergence of an increasing number of such studies (Kobozeva, Mikhailova, Shipova et al.).

According to the cognitive-discursive theory of metaphor (Chudinov, 2001, 2003, 2013), while describing the metaphorical model, it is proposed to characterize such parameters as the original and new conceptual spheres (source sphere and magnet sphere), which structure their typical scenarios, frames and slots. For example, the model "Political realities is the human body" appears in the form of frames "human body", "physiological organs", "body parts", "physiological actions", etc. The frame "physiological actions" consists of slots "nutrition, digestion and adjacent processes" (глотать, переваривать), "sleep (and its phases)" (дремать, спать, спячка), "breath" (дышать, перекрыть кислород), etc.

The cognitive-discursive theory of metaphor acquired quite a few followers in the East Slavic linguometaphorology (Budaev, Filatenko, Ryaposova et al.). In the existing works, the data of scientific research is a sphere-target (type of discourse) and the description of metaphorical models is reduced, as a rule, to an inventory and classification of spheressources of metaphorical nomination and their frame-slot structure.

The linguistic-cognitive study of metaphorics and the description of metaphorical models were carried out to a greater extent on the data of political discourse (Baranov, Budaev, Kerimov, Ryaposova, Filatenko, Chudinov et al.), and to a lesser extent artistic, scientific, medical, ecological, economic, pedagogical discourses (Kabachenko, Shinkarenkova et al.).

Consequently, when describing a metaphor as a cognitive model, it is usually indicated its parameters: the conceptual spheres of the source and the target of the metaphorical projection (or only the sphere of the source), their frames and slots. In the cognitive approach, conceptual convergence is perceived as a factor much more important than level or structural differences. As a result, when describing metaphorical models, restrictions defining features of the semantic approach are eliminated (a clear structure of models by semantic fields / micro-fields, lexicosemantic / thematic groups, etc., which includes the deriving and derived meanings, the seme's hierarchy). This leads to certain discrepancies in the representation of frame-slot characteristics of the same conceptual spheres. In general, cognitive studies of metaphor are distinguished by the scale of the material represented in them, the thoroughness of its systematization, and a detailed analysis of the structure of metaphors. However, in some works, metaphor is understood very broadly and often includes, as a research data, the facts of metonymy, paraphrases, comparisons, phraseological units.

\subsection{Semantic-cognitive Modelling of Metaphorisation.}

The author of this article (Kravtsova, 2011, 2014) has developed a new semanticcognitive approach to the study of metaphors and modelling of metaphorisation. According to it, a metaphor is considered as a phenomenon of language and thinking. Through the study of the semantics of the metaphorical nominations of any language and the construction of appropriate metaphorical models it allows to establish the models of national metaphorical thinking, which are typical for certain historical period. The study of cognitive processes, including metaphorisation, is possible only based on the research of the results of their realization in language (speech).

Metaphor is understood as a mental and verbal construct intended for characterisation and nomination of an object and created based on its analogy or associative similarity with another object, which already has a name, in the process of human cognitive activity. As it is known metaphor plays a significant role in the cognition and understanding of human reality. On the one hand, it serves to name certain phenomenon, objects, processes, etc., which 
contributes to the formation of a figurative concept of this reality. On the other hand, the constant use of the same metaphor in relation to a particular object of reality allows us to form a stereotypical view of it.

Metaphorisation is a cognitive and semantic mechanism that allow to detect commonality among various objects of reality based on the analogue and associative complexes existing in the minds of representatives of certain ethnoculture. Human thinking has all abilities that are necessary for metaphorisation: to analyse the perceived objects and situations, to compare different entities, to draw analogies among similar ideas about these or that realities. Thus, in the process of cognition of reality, a human highlights important elements for him, decomposes them into parts in his mind and then interprets what he has perceived, based on the components he has laid apart. The results of such a figurative cognition of reality are fixed in language (speech).

Metaphorical modelling can be defined as the construction of metaphorisation models that reflect the national stereotypes of the figurative analogue or associative thinking of any ethnocultural community (or individual ideas about the world of a native speaker) at a particular stage of historical development.

Technique of semantic-cognitive metaphorical modelling developed by the author is based on the following principles: understanding of a metaphor as a mental and linguistic phenomenon; synthesis of ideas of semantic and cognitive metaphorical modelling; implementation of metaphorical modelling based on the reconstruction of fragments of a national (or individual) metaphorical picture of the world; analysis of the representative corpus of metaphorical contexts; description of the metaphorical model as a three-component structure - original and new denotative-conceptual spheres, semantic-cognitive formant, which deal with a manifestation of metaphorical motivation (base of metaphorisation); the establishment of regular / frequency and productive metaphorical models; the possibility of structuring the metaphorical models as components of the mega-model and organisation of sub-models.

According to the outlined principles, a metaphorical modelling is carried out in several stages: 1) analysis and systematisation of metaphoric nominations of representative sample (studying various metaphorical contexts and establishing links among them); 2) the construction of metaphorical mega-models, models and sub-models (the ascertainment of the basic structures - mega-models and models, but then the detailing of every model, the identification of sub-models); 3) analysis and systematisation of metaphorical models (finding out the general properties of different mega-models and models based on which they are systematised); 4) summarising the preliminary results of the study of models (comparison of metaphorical models, the detection of the general and the particular, the ascertainment of the consistent patterns of metaphorical modelling); 5) analysis of the obtained results and their application (verification of the simulation results, elucidation of the extent of their practical application and the nature of their use in the further development of the theory of metaphorical modelling).

The developed technique of constructing and describing metaphorical models can be used: 1) as an independent operational mechanism in the semantic analysis of metaphorisation facts or a mandatory stage of the semantic-cognitive research of metaphors; 2) as in the corpus study of the metaphors of texts or discourses and in the study of separate facts of metaphorisation, which makes it universal. In addition, depending on the research objectives, it is possible to modernise the structure of the description of metaphorical models (for example, to exclude sub-models).

The metaphorical model is understood as a scheme of verbalization of correlative in analogue and associative terms of notions that exist in the minds of native speakers. The 
parameters of the model should clearly reflect the essence of the metaphorical nomination process, describing the following main stages: the motivation (basis) of metaphorisation the source of metaphorisation - the target of metaphorical projection (the metaphor itself). According to it, a metaphoric model is a three-component structure that includes original and new denotative-conceptual spheres, semantic-cognitive formant, which reflect the metaphorical motivation (for example, "human physical properties $\rightarrow$ atmospheric phenomenon | sound"). The ideographic way of representing the metaphorisation spheres (original and new) makes it possible to understand the system of logical and conceptual connections between motivating and motivated meanings. In such a description, spheresource (denotative-conceptual sphere of motivating meaning) and sphere-target (denotativeconceptual sphere of motivated meaning), that are common for semantic and cognitive modelling, are topical and the grammatical differences are eliminated, that is typical for cognitive studies (in the semantic studies, descriptions are usually carried out based on certain parts of speech).

One of the most important parameters of the metaphoric model is the semanticcognitive formant (my term - Yu. K. - that was introduced to describe a metaphor as a semantic-cognitive model) are a formal indicator of metaphorical motivation. Metaphorical motivation is understood as the relation of the original conceptual sphere (primary meaning) and the new conceptual sphere (secondary meaning) based on the common semanticcognitive sign of different objects of reality. The semantic- cognitive formant is mental and semantic element that integrate different entities similar in some relationship. It act as a motivating sign of a metaphorical projection from the original conceptual sphere into a new one. In other words, it is a semantic component that connect the conceptual spheres of the deriving and derived (metaphorical) meanings and reflect the system relations of linguistic and cognitive structures. The semantic-cognitive formants are formulated as "form", "sound", "colour", "dynamics", etc. This terminological designation makes the content topical and typical for the formant (the conceptual spheres that form this) and displays the systemic relations of cognitive and language structures, emphasizing the essence of metaphor as a phenomenon of language and thinking.

To describe the results of metaphorical modelling, we introduced the notions of metaphoric mega-model and sub-model. The number of metaphorical models with similar conceptual spheres forms a mega-model, i. e. the direction of a metaphorical projection from one ideographic sphere to another, formulated in the most general form. A metaphorical model can have variations that are a means of its specification and are characterized by the variability of the original and / or new conceptual spheres and / or semantic-cognitive formant within a given invariant (model) called sub-models. For example, the metaphorical model "the physical properties of human $\rightarrow$ atmospheric phenomenon $\mid$ sound" is implemented in the following sub-models: speech $\rightarrow$ precipitation | sound power: голоса дождя; молчанье снегов (Gippius); дождь шептал (Inber); speech $\rightarrow$ precipitation | sound power + sound quality: бормотание дождя; лепет дождя (Gippius, Inber); speech $\rightarrow$ airflow | sound power: голоса ветра (Bely, Tsvetaeva); крик ветра (Tsvetaeva), etc. In turn, this metaphorical model is a part of the mega-model "Human $\rightarrow$ Inorganic World".

As a result of a corpus study of the metaphors of Russian poetry and prose of the first half of the XX century (Bely, Gippius, Inber, Tsvetaeva et al.) based on the existing works on the cognitive metaphorical modelling (Baranov, Chudinov et al.), ideographic dictionaries (Baranov, Karaulov) and own observations on the facts of metaphorisation have developed a classification of spheres-sources and spheres-targets of metaphorical projection. They are the parts of the following seven mega-spheres: "Human" (physical, physiological, psychical, 
soulful properties of a human); "Socium" (social groups; social relations; art; as a spheresource also: the army); "Fauna" (animal species; as sphere-source also: animal groups; physical properties and habitat conditions of animals); "Flora" (types and totality of plants; physical properties of plants; plant physiology); "Inorganic world" (physical and atmospheric phenomenon; cosmic, terrestrial and water bodies; minerals; gemstones); "Artifact" (buildings; housewares; foodstuffs; clothing; tools; equipment; military attributes); "Time" (properties of time; time intervals). As spheres-sources of metaphoric projection in fictional texts, the most often are the denotative-conceptual spheres "physical properties of a human", "physiological properties of a human", "physical properties of animals", "physical phenomenon", "water objects", "minerals", "buildings", "clothes".

Analysis of the facts of metaphorisation from fiction based existing works on the problem of metaphorical motivation (Laguta, Usminsky et al.) allowed to identify the main semantic-cognitive formants that motivate the metaphorical projection: form (outlines, structure), colour (tone, hue), sound (pitch, strength, tempo, rhythm, sound quality), dynamics (movement, action, development), quantity (multitude, small quantity), measure (size, degree of smth.), correlation (order, location, connection), object manifestations (detection, intensity, activity, reaction to smth., realisation), consistency (density, transparency, hardness), condition (type, character), time (duration, continuity, sequence), functionality (purpose), assessment (positive / negative).

The obtained data and the analysis of the results achieved by different scholars demonstrated that the revealed integral semes of the motivating and motivated meanings on different data are very similar. It indicates the objectivity of the conducted studies. However, there are still many controversial and unresolved issues in linguistics, the study of which should lead to the development of a general typology of the signs that motivate the metaphorical projection.

\section{Conclusions.}

In conclusion it should be noted that in modern linguistics modelling is one of the main methods for studying various linguistic phenomenon and consists in constructing models that recreate certain properties of the objects being modelled. Metaphor in recent years has also become regarded as a simulated object. In accordance with different linguistic approaches, it is described as a semantic or cognitive model, in the construction and description of which different ways of parameterization are used.

According to the proposed semantic-cognitive approach, metaphorical model is a scheme of verbalisation of correlative in analogue and associative terms of concepts that exists in the minds of native speakers. It is a three-component structure, including original and new denotative-conceptual spheres (sphere-source and sphere-target), semanticcognitive formant. The developed technique of metaphorical modelling can be used in the study of both large metaphors corpus in texts or discourses of various genre-style qualifications, as well as separate facts of metaphorical nomination.

The main point of the semantic-cognitive approach to the study of metaphors is that through the study of the semantics of metaphorical nominations and the construction of metaphorical models reconstructed as a result of analysing any fragment of the language picture of the world, it is possible to reveal models of the national (or individual) metaphorical thinking typical for a certain historical period.

The further development of the theory and practice of metaphorical modelling based on the data of various languages in descriptive and comparative aspects is one of the promising directions of linguometaphorology. Conducting such studies will contribute to a deeper penetration into the essence of metaphorisation, identification and systematisation of productive metaphorical models at different stages of the evolution of one or the other 
language, generalisation of the results of scientific research and objectivity of describing the processes of metaphorical nomination, which will open up great opportunities for ascertainment general trends of metaphorical modelling of reality.

\section{References}

Apresjan, Ju. D. (1966). Idei i metody sovremennoj strukturnoj lingvistiki [Ideas and methods of modern structural linguistics]. M. : Nauka.

Balashova, L. V. (2014). Russkaja metafora. Proshloe, nastojashee, budushee [Russian metaphor. Past, present, future]. M. : Jazyki slavjanskoj kultury.

Baranov, A. N. (2004). Kognitivnaja teorija metafory: pochti dvadtsat pjat let spustja [Cognitive theory of metaphor: almost twenty-five years later]. Metafory, kotorymi my zhyvjom. eds Dzh. Lakoff, M. Dzhonson; Per. s angl. A. N. Baranova, A. V. Morozovoj. M. : Editorial URSS. 7-21.

Baranov, A. N. (2014). Deskriptornaja teorija metafory [Descriptor Theory of Metaphor]. M. : Jazyki slavjanskoj kultury.

Baranov, A. N., Mikhajlova, O. V., Shypova, E. A. (2006). Nekotorye konstanty russkogo politicheskogo diskursa skvoz prizmu politicheskoj metaforiki [Some constants of Russian political discourse through the prism of political metaphors]. M. : Indem.

Baranov, O. S. (2002). Ideograficheskij slovar russkogo jazyka [Ideographic dictionary of the Russian language]. M. : Russkij jazyk.

Belyj, A. (1996). Izbrannoe [Selected works]. Rostov-na/D : Feniks.

Bloomfield, L. (1968). Jazyk [Language]. M. : Progress.

Budajev, E. V., Chudinov, A. P. (2013). Kognitivnaja teorija metafory: novye gorizonty [Cognitive theory of metaphor: new horizons]. Izvestija Uralskogo federalnogo universiteta. Ser. 1. Problemy obrazovanija, nauki i kultury, 1 (110). 6-13.

Chudinov, A. P. (2001). Rossija v metaforicheskom zerkale: kognitivnoe issledovanie politicheskoj metafory (1991-2000) [Russia in a metaphorical mirror: a cognitive study of political metaphor (1991-2000)]. Ekaterinburg : Izd-vo UrGPU.

Chudinov, A. P. (2013). Ocherki po sovremennoj politicheskoj metaforologii [Essays on modern political metaphorology]. Ekaterinburg : Izd-vo UrGPU.

Filatenko, I. A. (2007). Kontseptualnaja kartina politicheskoj dejstvitelnosti sovremennoj Ukrainy (opyt metaforicheskogo modelirovanija) [Conceptual picture of the political reality of modern Ukraine (the experience of metaphorical modelling).]. Cuadernos de Rusistica Espanola. 3. Granada. 155-161. literatura.

Gippius, Z. N. (1991). Sochinenija: Stikhotvorenija. Proza [Works: Poems. Prose]. L. : Khudozhestvennaja

Glushkov, V. M., Ivanov, V. V., Janenko, V. M. (1983). Modelirovanie razvivajushikhsja sistem [Modelling of developing systems]. M. : Nauka.

Harris, Z. (1951). Methods in structural linguistics. Chicago : University of Chicago Press.

Inber, V. (1965). Sobranie sochinenij: v 4 t. T. 1. Stikhotvorenija i poemy [Collected Works: 4 t. T. 1. Poems and poems]. M. : Khudozhestvennaja literatura.

Kabachenko, E. G. (2005). Ekonomicheskaja metafora v sovremennom pedagogicheskom diskurse [Economic metaphor in modern pedagogical discourse]. Izvestija Uralskogo gosudarstvennogo pedagogicheskogo universiteta. Ligvistika, 16. 155-161. jazyk.

Karaulov, Ju. N. (1976). Minimalnyj ideograficheskij slovar [Minimal ideographic dictionary]. M. : Russkij

Kerimov, R. D. (2013). Zoometafory v jazyke nemetskoj politiki (lingvokognitivnyj aspekt) [Zoometaphors in the language of German politics (linguocognitive aspect)]. Vestnik Permskogo universiteta. Rossijskaja $i$ zarubezhnaja filologija, 2 (22). 58-67.

Kobozeva, I. M. (2001). Semanticheskie problemy analiza politicheskoj metafory [Semantic problems of analyzing political metaphors]. Vestnik MGU. Ser. 9. Filologija, 6. 132-149.

Kravtsova, Ju. V. (2011). Metaforicheskoe modelirovanie mira: poezija i proza [Metaphorical modelling of the world: poetry and prose]. Kiev : Izd-vo NPU im. M. P. Dragomanova.

Kravtsova, Ju. V. (2014). Metaforicheskoe modelirovanie mira v khudozhestvennom tekste: semantikokognitivnyj analiz [Metaphorical modelling of the world in the artistic text: semantic-cognitive analysis]. Kiev : Izdvo NPU im. M. P. Dragomanova. 
Kudrjavtseva, L. A. (2004). Modelirovanie dinamiki slovarnogo sostava jazyka [Modelling of vocabulary dynamics]. 2-e izd., dop. K. : Kievskij universitet.

Laguta, O. N. (2003). Metaforologija: teoreticheskie aspecty. Ch. 2. Lingvometaforologija: osnovnye podhody [Metaphology: theoretical aspects. P. 2. Linguometaphology: main approaches]. Novosibirsk : Izd-vo NGU.

Losev, A. F. (1968). Vvedenie v obshchuju teoriju jazykovykh modelej [Introduction to the general theory of language models]. M. : Nauка.

Ponomareva, O. B. (2005). Kognitivnye i pragmastilisticheskie aspekty semanticheskoj derivatsii (na materiale anglijskogo jazyka $v$ sopostavlenii s russkim i nemetskim jazykami) [Cognitive and pragmatic aspects of semantic derivation (based on the material of the English language in comparison with the Russian and German languages)]. Tjumen : Izd-vo TjumGU.

Rezanova, Z. I., Mishankina, N. A., Katunin, A. D. (2003). Metaforicheskoe modelirovanie v jazykovoj kartine mira (k obosnovaniju metodov issledovanija) [Metaphorical modelling in the language picture of the world (to the justification of research methods)]. Vestnik Tomskogo gosudarstvennogo universiteta. Ser. Filosofija. Kulturologija. Filologija, 277. 164-171.

Revzin, I. I. (1978). Struktura jazyka kak modelirujushchej sistemy [The structure of the language as a modelling system]. M. : Nauка.

Rjaposova, A. B. (2001). Militarnaja metafora v sovremennom agitatsionno-politicheskom diskurse [Militar metaphor in modern agitational-political discourse]. Lingvistika. Bjulleten Uralskogo lingvisticheskogo obshestva, 6. 43-49.

Shmeljov, D. N. (1964). Ocherki po semasiologii russkogo jazyka [Essays on the semasiology of the Russian language]. M. : Nauka.

Shtoff, V. A. (1966). Modelirovanie i filosofija [Modelling and philosophy]. M.-L. : Nauka.

Shynkarenkova, M. B. (2003). Militarnaja metafora v rok-poezii [Militar metaphor in rock poetry]. Lingvistika. Bjulleten Uralskogo lingvisticheskogo obshestva, 10. 34-45.

Skljarevskaja, G. N. (1993). Metafora v sisteme yazyka [Metaphor in the language system]. SPb. : Nauka.

Solodovnikova, N. V. (2011). Metaforicheskoe modelirovanie v publitsysticheskom diskurse [Metaphorical modelling in journalistic discourse]. Kultura narodov Prichernomorja, 206. 58-60.

Telija, V. N. (1988). Metafora kak model smysloproizvodstva i jejo ekspressivno-otsenochnaja funktsija [Metaphor as a model of semantic production and its expressive-evaluative function]. Metafora v jazyke i tekste. 2652.

Tropina, N. P. (2003). Semanticheskaja derivatsija: multiparadigmalnoe issledovanie [Semantic derivation: a multiparadigm study]. Kherson : Izd-vo HGU.

Tsvetaeva, M. I. (1990). Izbrannoe [Selected works]. M. : Prosveshenie.

Usminskij, O. I. (1996). Sensornye tropy: klassifikatsija, znachenija, funktsii [Sensory figurative means: classification, values, functions]. Tjumen : Izd-vo TGU.

Vardzelashvili, Zh. A. (2001). Metaforicheskie nominatsii v russkom jazyke [Metaphorical nominations in Russian]. Tbilisi : izd-vo TGPU im. S.-S. Orbeliani. Nauka.

Vedenov, A. A. (1988). Modelirovanie elementov myshlenija [Modelling the elements of thinking]. M. :

\section{Бібліографічний опис:}

Кравцова, Ю. В. (2018). Метафоричне моделювання в сучасних лінгвістичних дослідженнях. Науковий часопис Національного педагогічного університету імені М. П. Арагоманова. Серія 9. Сучасні тенденції розвитку мов, 18. 95-106. DOI: https://doi.org/10.31392/NPU-nc.series9.2018.18.08

\section{Анотація}

У сучасній науиі моделювання є одним з основних методів наукового дослідження. Метафора стала розглядатися як модельований об'єкт лише з кіния минулого століття. У східнослов'янській лінгвістиці сформувалося два підходи до моделювання метафоризаиї - семантичний $і$ когнітивний. На основі аналізу лінгвістичних досліджень з метафоричного моделювання схарактеризовано різні способи параметризації метафори як семантичної та когнітивної моделі, встановлено їхні спільні параметри, висвітлено дискусійні питання. Автором розроблений новий семантико-когнітивний підхід 
до вивчення метафори та моделювання метафоризації, згідно з яким метафора розуміється як ментально-вербальний конструкт, щзо створюється у процесі метафорогенної діяльності людини. Однак вивчення когнітивних механізмів, у тому числі метафоризації, є можливим тільки на основі дослідження результатів їхньої реалізації в мові (мовленні). Семантико-когнітивний підхід дозволяє через дослідження семантики метафоричних номінацій будь-якої мови та побудову відповідних метафоричних моделей встановити моделі метафоричного мислення етносу, характерні для того чи того історичного періоду. Стисло викладено основні положення такого підходу, представлено параметричний опис метафори як семантико-когнітивної моделі, надано обгрунтування введених понять метафоричної мегамоделі та субмоделі, семантико-когнітивного форманта. Запропонована методика призначена як для корпусного дослідження метафор, так $і$ для вивчення окремих фактів метафоричної номінації.

Ключові слова: метафора, метафоризачія, метафоричне моделювання, метафорична модель, параметр моделі, сфера-джерело, сфера-иџіль. 